\title{
Can biotechnology contribute to the development of research and innovation smart specialization strategy (RIS3) in Central and East European countries? Reminiscences from the European Workshop
}

\author{
Miroslav Ondrejovič ${ }^{1}$ and Stanislav Miertuš $\check{1}^{1,2 *}$
}

\begin{abstract}
The paper presents main results and recommendations of the recent European Workshop dedicated to the evaluation of current state and prospects for Biotechnology with the attention to Central and European countries. The contribution of Biotechnology to the RIS3 strategy is also briefly presented. It is believed that there is still insufficient integration of research and innovation, especially in Central and Eastern European countries. Another problem is the weak interest and lack of mechanisms for the entry of potential investors into biotechnology capital-intensive areas. Series of proposals and recommendations coming from the Workshop on how to increase the regional cooperation in the field of Biotechnology is briefly described together with the potential role of international institutions (JRC-EC, CEI, ICGEB, EBTNA) in such cooperation.
\end{abstract}

Keywords: Biotechnology, research and innovation smart specialization strategy, cooperation in biotechnology in Central and East European countries, current state and prospects

'Department of Biotechnology, Faculty of Natural Sciences, University of SS. Cyril and Methodius in Trnava, Trnava, Slovakia ${ }^{2}$ International Centre for Applied Research and Sustainable Technology, Bratislava, Slovakia

${ }^{*}$ Corresponding author: S. Miertuš E-mail: stanislav.miertus@ucm.sk

DOI: 10.2478/ebtj-2018-0011
(C) 2018 Authors. This work was licensed under the Creative Commons AttributionNonCommercial-NoDerivs 3.0 License.

\section{Introduction}

A European Workshop on "Smart Specializations Strategy in the Field of Biotechnologies in Europe: A Challenge for Central and East European Countries (CEE)" was organized from September $4^{\text {th }}$ to September $6^{\text {th }} 2017$ in Bratislava (Slovak Republic) by Faculty of Natural Sciences of University of SS. Cyril and Methodius in Trnava in cooperation with Slovak Academy of Sciences and International Centre for Applied Research and Sustainable Technology, Bratislava with the funding and expertise support of the Joint Research Centre of European Commission (JRC-EC), Brussels, the Central European Initiative (CEI) and the International Centre for Genetic Engineering and Biotechnology (ICGEB) both in Trieste, Italy. The event was held under auspices of Ministry of Education, Science, Research and Sport of the Slovak Republic and Ministry of Foreign and European Affairs of the Slovak Republic.

JRC-EC - CEI - ICGEB European Workshop was opened to researchers, technologists, industrial representatives and entrepreneurs, experts, and representatives from international organizations and NGO, governmental officers, involved in the field of Biotechnology from through Europe.

The Workshop was focused on the survey and evaluation of current state and prospects of development of research and innovation areas included within Research and Innovation Smart Specialization Strategy (RIS3) in many European countries with particular focus on the Biotechnology and on regional cooperation of CEE countries. The overall objective of the Workshop was to further promote Research and Innovation with the attention to CEE countries in the field of Biotechnology ranging from industrial biotechnology, bio-based industries and bio-economy, through environmental, agro-food 


\section{Areas of Economic Specialisation}

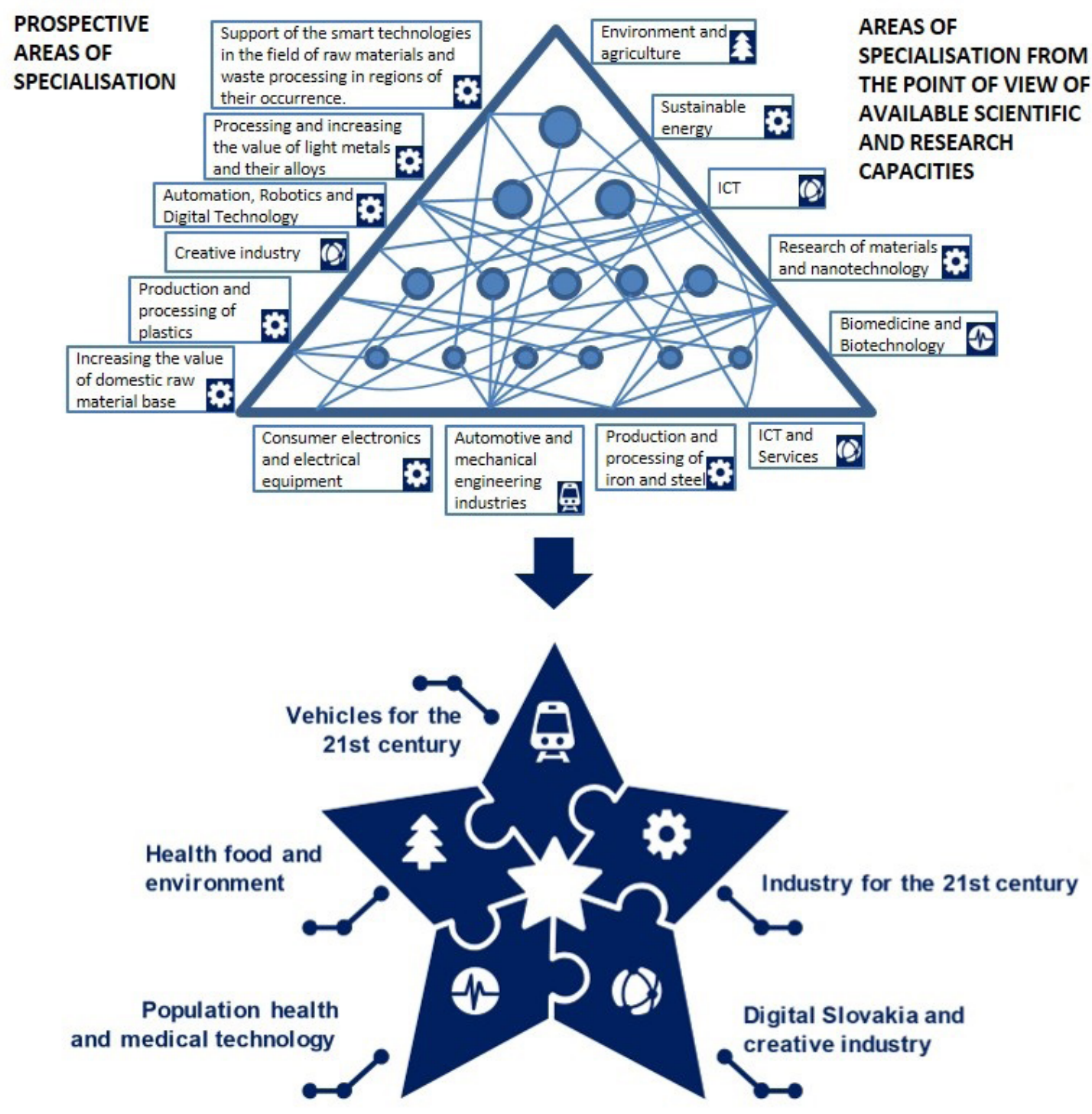

\section{Smart Specialisation Domains}

Figure 1. Central role of Biotechnology (1).

biotechnology up to medicinal and pharma biotechnologies. The Workshop aimed at providing a forum for discussion between multi-sectorial stakeholders to share knowledge and experience and to formulate recommendations on national and regional level towards increasing smart specialization, competitiveness and impact on related biotech industries, strengthening regional cooperation within European research programs as well as cooperation with international organizations such as JRC-EC, ICGEB, CEI and EBTNA. More than 100 experts from 22 European countries participated at the Workshop.

\section{Workshop Program}

The first part of scientific lectures focused on key topics of the workshop were grouped in the following sessions: Introduction to smart specialization strategy, Key lectures on Biotechnology progress and prospects, Bio-refinery concepts and perspectives, Novel breeding technologies and Future medicinal biotechnologies. This was continued by presentations of International programs to support biotechnologies and bio-based industries development relevant to RIS3 (EC Horizon 2020, ICGEB, JRCEC, CEI, EBTNA).

The second part was dedicated to Industrial and environmental biotechnologies, "Green" agro-food biotechnologies, Medicinal and pharma biotechnologies including Pharmacology, Gene therapy, diagnostics and Stem cells, tissue engineering, bio-additive manufacturing and regenerative medicine. 


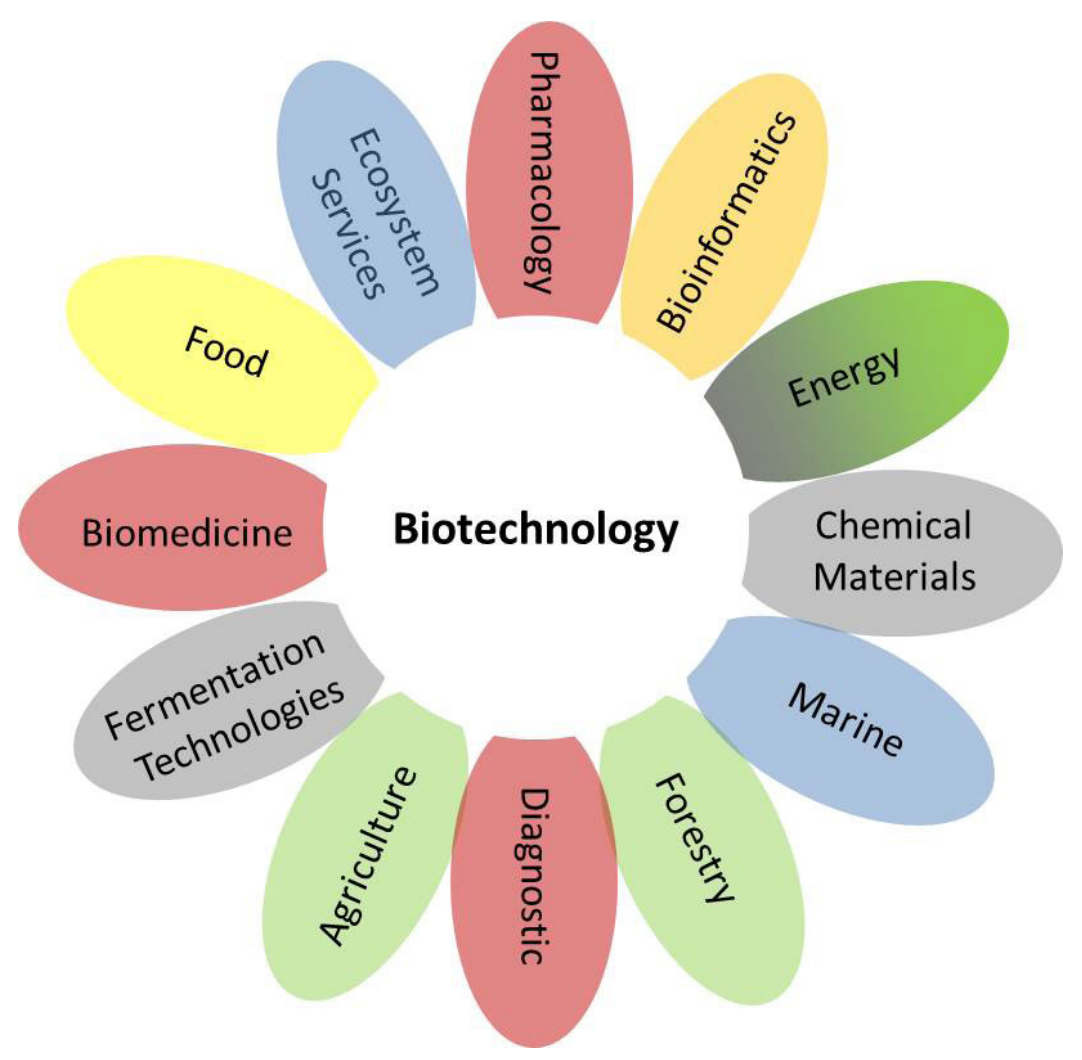

Figure 2. Smart Specialisation - the concept strategy in Slovakia $(2,3)$.

These were followed by Development of national and regional cooperation in biotechnologies - role of biotechnology centers and clusters and the Bio-economy. The third day of the Workshop was focused on the following topics: From biotechnology research to innovation and industry; public-private partnership; future bio-based high tech industries, country reports and regional cooperation in biotechnology - the role of international programs. The final part of the Workshop was dedicated to a discussion on possible follow-up actions and recommendations.

\section{Results and Outputs}

Key lectures provided the overview of current state and progress in individual fields of biotechnology, keeping in mind that biotechnology should play a central role for several key sectors of Smart Specialization Strategy (Fig. 1, 2). Smart specialization is an innovative approach of the European Commission promoting efficient and targeted use of public investment in research and innovation to enable countries and regions to capitalize on their strengths and create new competitive advantages. National and regional smart specialization strategies serve as compasses for European Structural and Investment Funds investments in research and innovation. In this context, the European Commission supports public authorities responsible for the allocation of investment resources with analysis and guidance (1).

Therefore, RIS3 strategy in various countries in Europe, especially in CEE countries is being developed within key sectors, which could vary from one country to another. However, the contribution of Biotechnology to the wide range of technology and innovation sectors is essential (Fig. 1).

Altogether 45 lectures were delivered, and 19 posters were presented. All presented lectures are available on the Workshop web site (4). The abstracts of all contributions are also accessible on the web-site of workshop (5). Selected lectures have been further elaborated and are being published in the form of full papers in the EuroBiotech Journal (6-8) as well as in a Special Issue of the Journal of Biotechnology (9-18).

The Workshop event has been widely reported (19-24). Another output of the Workshop is the survey and evaluation of the current situation and prospects in Biotechnology in Central and East European countries which has been also submitted for publishing to the international scientific journal (Critical Reviews in Biotechnology) $(25,26)$.

Discussion in the final section of the Workshop leads to the series of proposals, recommendations and to possible followup actions.

\section{Concluding remarks and recommendations}

Participant's contributions evaluated current trends in research, innovations and cooperation in the field of Biotechnologies as well as in the Bio-economy. Presented contributions and discussion referred to various problems in Biotechnology research, innovation, relevant industrial development as well as to various forms of regional and international cooperation, need modern approaches in education ( $\mathrm{PhD}$ programs, Masters) etc.

Regarding part of industrial biotechnology and biomass uti- 
lization it was emphasised that biomass is a limited resource used within the food market and the markets for raw materials as well as the energy markets. To supply all these markets based on relatively small amounts of fertile land political measures need to be urgently implemented to use biomass more efficiently. The bio-refinery approach is a very promising option in this respect. Biomass is a priori a decentralized source. Thus innovative bio-refinery approaches have to take care of this and should to be also technologically possible on the farm scale. Biogas plants can act as a sink basically for any kind of organic waste material (except wood). Biogas plants can act as a core component of such innovative bio-refinery approaches realized on the small scale.

It was also stated that biotechnology is a central part of the Bio-economy and Biomedicine and smart specialization strategies should take account of its innovation potential in relation to the relatively high importance of primary production in the CEE region, as well as the development of a low-carbon, prosperous regional economy able to compensate the structural changes in the primary production sector. The workshop showcased the high level of biotechnology research in the region but also the synergistic potential that would lie in interregional cooperation in this field. However, the view of local business and hence the discussion of how to convert the scientific excellence in the region into marketable products should be strengthened in follow-up actions. The RIS3 program has to support this and the JRC-EC together with other international organizations is available to support followup events to this workshop widening the range of participating stakeholders.

It has been shown that in CEE countries the elaboration and implement of RIS3 strategy is progressing slowly. Although Biotechnology plays a central role in various branches of research, development and innovation (Fig. 1), the RIS3 strategy would need to define a strategic and coordinated plan of implementation with clear accent on how biotechnology can contribute to the grow of high-tech industries.

As individual countries of CEE region might not have the critical mass for a given priority development, like biotech based bio-refineries, or clinical testing of new bio-medical products, the initiatives on the setting-up of collaborative inter-regional networks is a highly topical issue. The S3-platforms (27) can provide support in this context and help to link-up with other national and international partners.

It was underlined that there is still insufficient integration of research and innovation, especially in Central and Eastern European countries. Another problem is the weak interest and lack of mechanisms for the entry of potential investors into biotechnology capital-intensive areas.

Therefore, there is an urgent need to set up of national and regional sectorial networks including various stakeholders (academia, applied research institutions, SMEs and hightech industries, governmental institutions, international organizations, etc.). It is especially important for the CEE region. Co-operating institutions JRC-EC, ICGEB, CEI,
EBTNA expressed full availability to support such a program.

Moreover, it was recommended by ICGEB representatives to continue and expand the workshop program in CEE countries. ICGEB is keen to continue support such this type of workshop, based on high level lectures, with the right formula (bringing together a mix from the European and local scientific community) and in conjunction with other international organizations (JRC-EC, EBTNA and CEI in particular). Another recommendation is to finance people development, not only infrastructure. ICGEB wished to stress the relevance of building human resources for research and technology transfer. The development of mobility fellowships, short-term $\mathrm{PhD}$ programs and joint research grant programs with the ICGEB labs would contribute increased of impact from research carried out in the CEE region.

It was also recommended to use digital learning for education especially using digital learning platforms, such as the ICGEB podcast program.

EBTNA representatives expressed interest to cooperate to the organization of Courses and Workshops in CEE region in collaboration with other national and international institutions participating in present Workshop, possibly also as joint satellite meetings with European Biotechnology Congress series (19). EBTNA also recommended promoting joint EuroBiotech Schools in Master Degree or related forms within EC framework programs also in cooperation with CEE countries focused on biotechnology. They expressed they expressed interest in supporting an open distance learning platform, which could be further promoted and used effectively together with other learning programs (e.g. ICGEB).

CEI representatives expressed the support for biotechnology knowledge transfer programmes in the CEE region focusing on biofuels, biobased products, industrial and green biotechnology and especially bioeconomy with links to other regional cooperative programs (Danube Initiative, Interreg, bilateral programs in CEE countries, etc.).

It was concluded that the implementation of these proposals and recommendations should be monitored by the panel of invited experts/governments representatives and evaluated at the next an European Workshop (possibly in 2019).

\section{Acknowledgement}

This work was also supported by the Slovak Research and Development Agency grants APVV-14-0294, APVV-15-0111 and APVV-16-0088.

\section{Conflict of interest statement}

The authors declare that they have no conflict of interest.

\section{References}

1. Kreysa J. BioEconomy, the key issues in Europe. JRC-EC - CEI ICGEB European Workshop "Smart Specialization Strategy in the Field of Biotechnologies in Europe: A Challenge for CEE Countries. Bratislava, 2017.

2. Pastorek J. RIS3 in Slovakia. Current state and relevance to biotechnology. JRC-EC - CEI ICGEB European Workshop "Smart Spe- 
cialization Strategy in the Field of Biotechnologies in Europe: A Challenge for CEE Countries. Bratislava, 2017.

3. Deputy Prime Minister's Office for Investments and Informatization of the Slovak Republic, Ministry of Education, Science, Research and Sport of the Slovak Republic, Ministry of Economy of the Slovak Republic, Government Office of the Slovak Republic: Implementation plan. Research and Innovation Strategy for Smart Specialisation of the Slovak Republic. 2017.

4. http://www.ris3-eu-biotech-workshop-2017.eu/presentations.

5. http://www.ris3-eu-biotech-workshop-2017.eu/book-of-abstracts.

6. Paneghetti L, Gallotta A, Parrozzani Ch, Fassina G. Biomarkers development for early detection of cancer: Reducing the burden of cancer in the ageing society. EuroBiotech J, to be published.

7. Nagy BJ, Makó M, Erdélyi I, Ramirez A, Moncada J, Gursel IV, Ruiz-Martínez A, Seco A, Ferrer J, Abiusi F, Reith H, Van den Broek LAM, Seira J, Garcia-Bernet D, Steyer JP, Gyalai-Korpos M. MAB2.0 project: Integrating algae production into wastewater treatment. EuroBiotech J. to be published.

8. Tirsu MS, Uzun GN. Renewables as important energy source for Moldova. EuroBiotech J. to be published.

9. Gartland KMA, Gartland JS. Opportunities in biotechnology. J. Biotechnol, to be published.

10. Findrik Balogová A, Franková K, Tóth T, Bakoš D., Feranc J, Živčák J, Hudák R. Determination of the geometrical and viscoelastic properties of PLA/PHB samples made by additive manufacturing for urethral substitution. J. Biotechnol, to be published.

11. Sládková A, Stopka J, Strižincová P, Šurina I, Kreps F, Burčová Z, Jablonský M, Sekretár S. Microwave-assisted method for extraction of spruce bark constituents. J. Biotechnol, to be published.

12. Mladenović D, Pejin J, Kocić-Tanackov S, Djukić-Vuković A, Mojović $L$. Enhanced lactic acid fermentation by adaptive evolution of Lactobacillus paracasei on agro-industrial waste substrate. J. Biotechnol, to be published.

13. Kraic J, Mihálik D, Klčová L, Gubišová M, Klempová T, Hudcovicová M, Ondreičková K, Mrkvová M, Havrlentová M, Gubiš J, Čertík M. Progress in genetic engineering of essential polyunsaturated fatty acids in cereals. J. Biotechnol, to be published.
14. Jablonský M, Škulcová A, Malvis Anna, Šima J. Extration of value-added components from food industry based and agro-forest biowastes by deep eutectic solvents. J. Biotechnol, to be published.

15. Burčová Z, Kreps F, Greifová M, Jablonský M, Ház A, Schmidt Š, Šurina I. Antibacterial and antifungal activity of phytosterols and methyl dehydroabietate of Norway spruce extracts. J. Biotechnol, to be published.

16. Legerská B, Chmelová D, Ondrejovič M. Decolourization and detoxification of monoazo dyes by laccase from the white-rot fungus Trametes versicolor. J Biotechnol, to be published.

17. Fira D, Dimkić I, Berić T, Lozo J, Stanković S. Biological control of plant pathogens by Bacillus species. J Biotechnol, to be published. Sparlinek L, Leitner V, Kamm B. Statistical experiment-based optimization of the enzymatic pretreatment of spent sulphite liquors using fungal laccases. J Biotechnol, to be published.

18. Official web site of the Workshop (http://www.ris3-eu-biotech-workshop-2017.eu).

19. Official communication/media tools of FNS of the UCM - web (http://fpv.ucm.sk) and Facebook.

20. Official communication/media tools of ICGEB - web (http://www. icgeb.org), Facebook, Instagram.

21. Official web site of the CEI (http://www.cei.int).

22. Official web site of the ICARST (http://www.icarst.org).

23. Press release sent to TASR (The News Agency of the Slovak Republic).

24. Dettenhofer M, Ondrejovič M, Vasáry V, Kaszycki P, Twardowski T, Stuchlík S, Turňa J, Dundar M, Gartland KMA, Miertuš S. Current state and prospects in Biotechnology in V4 Central and East European countries (Czech Republic, Slovakia, Hungary, Poland). Crit Rev Biotechnol 2018, to be published.

25. Dettenhofer M, Ondrejovič M, Kurtanjek Ž, Slavica A, Begovic J, Nedovic V, Tapaloaga D, Tapaloaga PR, Pojskic L, Durmic A, Dundar M, Gartland KMA, Miertuš S. Current state and prospects in Biotechnology in new and pre-accession Central and East European countries (Croatia, Romania, Serbia, Bosna and Herzegovina). Crit Rev Biotechnol 2018, to be published.

26. http://s3platform.jrc.ec.europa.eu/. 